\title{
The Vale of Tears: Kashmir, the Source of Indo-Pakistani Conflict Since 1947
}

\author{
Isiaka Alani Badmus \\ Centre for Social Science Research and Development, P.O. Box 214, Ikorodu, Lagos, Nigeria \\ Telephone: +234-8038034974; E-mail: isiakabad@excite.com,badmus_in_nigeria@yahoo.co.uk
}

KEYWORDS Pakistan. India. Jammu and Kashmir. Religion. War

ABSTRACT This study is a contribution from Africa to the scholarly discourse on India - Pakistan strained international relations. From historical and descriptive perspectives, it critically analyses the present estrangement between the two South Asia giants over Jammu and Kashmir between 1947 and 2000. The central thesis of this study is that the Indo-Pakistani conflict is an extension of the century old Hindu-Muslim tension within the subcontinent to the inter-state relations between the two countries. Within this context, it postulates that the conflict is more of religion that is being camouflaged with politics, and argues further that unless the fundamental causes of militancy and people's disenchantment are tackled, no worthwhile and lasting solution is possible. As a result, the article suggests that India and Pakistan should note that the problem in Kashmir can never be resolved through the barrel of the gun. Thus, a political solution that could satisfy the urges and aspirations of the people of Jammu and Kashmir living in all regions and areas and belonging to all faiths and communities that could be eventually acceptable to the two parties is called for

Sadly, alarmingly, endlessly, there is trouble in paradise. The vale of Kashmir, once exalted for the lotus

blooms in its lakes and the yellow tapestry of its mustard fields, has become a valley of despair-a place of haunted by senseless murder and hideous torture, wherever the famously sweet winds blow

- Barry Bearak, New York Times, 12 August, 1999.

\section{INTRODUCTION:A PEEP INTO HISTORY}

The above quotation aptly wraps up the long tradition of harmony, love and gladness of joys that once existed in Kashmir before it turned out to be the theatre of war with macabre of killings, with people blown apart, ambushed, caught in cross fire, despair and overwhelmed by the culture of gun and morality of mercenary. The IndoPakistani conflict (hereinafter referred to as the Indo-Pak conflict) centres on the control of the princely state of Jammu and Kashmir, which ultimately developed into an irredentist/antiirredentist relationship between the two countries. The genesis of the unresolved Kashmiri problem is as complex as it is disputed in the view of divergent perception of relevant history Political, Legal, and Constitutional. Historically, the Kashmiri imbroglio can be traced back to the days before the division of the subcontinent (Guptar, 1973: 440). As a matter of fact, the major elements of the conflict are the negative images that the Indians and Pakistanis had of themselves on the eve of the partition, the antithetical nature of Hinduism and Islam and the consequences of the British 'cut and run' departure from the Subcontinent (the British India) (Burke, 1947: 1011).
The present conflict started in June 1947 when the decision was made to divide the Subcontinent. The departing British colonial masters demanded that the subcontinent's 562 landed Maharajahs should opt for either of the two new Dominions. It was the recommended that the whishes of the people and the geographical realities of the states should be taken into account. Before the partition actually took place on 15 August, 1947, all the princely states with three exceptions-Junagadh, Hyderabad, and Jammu and Kashmir had come to a decision. Both Junagadh and Hyderabad were not contiguous with Pakistan and had Hindu population with Muslim ruler. While the state of Jammu and Kashmir (which under the British was governed as a semi-autonomous region) bordered with Pakistan and was predominantly Muslim with unpopular Hindu monarch (Burke, 1975: 17). It was the vacillation of Maharajah Hari Singh, the rich and incompetent Jammu and Kashmir monarch, and his predominantly Hindu administration in deciding on whether to join India or Muslim Pakistan or remain independent after the transfer of power that created the problem. After the power was actually transferred, the British hegemony lapsed and legally and constitutionally, Jammu and Kashmir became a 
full sovereign state and remained so until 27 October, 1947 (Bercovitch and Jackson, 1996: 186).

However, when the Pakistani tribesmen invaded Kashmir in October, 1947, the Hindu Maharajah opted for accession to predominantly Hindu India by signing the Instrument of Accession (IOA) under peculiar circumstances, saying that, "the other alternative is to leave my state and people to freebooters". That decision was not readily acceptable to Pakistan and largely Muslim Kashmiris who felt that the land had fallen under the thumb of the infidels. Thus, they have always contested the decision to include Kashmir into India. This state of affairs, ultimately, led to tension between the two countries and finally culminated into the first Indo-Pak war of 1947/48 with enormous human and material losses to both sides. The timely intervention of the United Nations (UN), through the United Nations Commission for India and Pakistan (UNCIP) precipitated a ceasefire agreement along the stabilized military front that finally brought the war to an end on 1 January, 1949 (Ganguly, 1986: 64-67; Naidu, 2005: 7).

Furthermore, the precarious truce and uneasy peace between the two countries flared-up into a full scale war in 1965 which made Pakistan to gain control of one-third of the territories, leaving the remaining two-third under India control. The cease-fire, the so called Line of Control (LoC), now serves as the quasi-border for the two countries. Also in 1970, another war broke out between the two sides primarily connected with the liberation of Bangladesh from Pakistan consequent upon the popular revolt in the former East Pakistan which later snowballed into Jammu and Kashmir. The 1972 Shimla Agreement brought the two countries to a peace path. Despite the 1972 peace agreement, lack of referendum on Kashmir has remained a thorny issue and which, in the words of Barry Bearak, "for more than 5 decades now, a puzzle without a solution is one of the world's most confounding morasses, a 53 years old custody battle where the contesting parties disagreed on the detail of every scarp of their common history" (New York Times, 12 August, 1999).

The State of Jammu and Kashmir, with a population of about 10 million and Srinagar as capital, has a total area of $222,236 \mathrm{sq}$. $\mathrm{km}$. It is made up of three parts; Kashmir province, Jammu province, and Frontier districts. Jammu and Kashmir is a multi-lingual, multi-ethnic and multi- religious state and not homogeneous entity. It is the creation of conquest and annexation by the former Dogra rulers. Hence, it is within the context of diverse ethnic groups with different ideological cum religious beliefs that Kashmir has been mired for more than 50 years in a battle for control by India and Pakistan (Brown, 1972: 179).

\section{PARTIES AND TIME PERIOD}

To really fathom the Indo-Pak conflict that is poisoning the relationship between the two South Asian countries, we must untangle the skin of events from 1989 (this was the period when the rebellion that have scarred Kashmir broke out) to 2000. Sometime, the study will go back into history to provide adequate historical details to sharpen our analytical insight into the forces that actually propelled this Inter-State war.

The Kashmiri conflict is complex and its complexity derives from the fact that different parties are involved. The primary parties to this conflict since the partition of the subcontinent are the governments of India, Pakistan, and Kashmir. The most important secondary actor is the United States of America (US) who has been the major financier and chief arms supplier to Pakistan in line with the Mutual Defense Assistance Agreement of 1954. In actual fact, the US military relationship with Pakistan in which the Americans arms ostensibly supplied as part of Washington's strategy to contain Communism in Post-Second World War international order is a source of apprehension to India. In addendum, the US offered Pakistan $\$ 3.2$ billion military and economic aid in September 1981 alone (Sreedhar and Kamiyalil, 1986). The US further assisted the Pakistani government by providing the latter with $40 \mathrm{~F}-16$ fight-bombers to improve her air defence system, naval armaments like anti ship Harpoon Missiles. In a nutshell, the US is a strong supporter of the Pakistani armed forces. This situation has led to security dilemma, as India feels completely insecure with the American assistance to her rival to the west. Hence, India has tried to increase and build up her own security by increasing the level of her armament.

As a global institution with the maintenance of world peace and security as its primary objective, the UN is another influential secondary party. The UN was drawn into the conflict when New Delhi under the able and charismatic leadership of Jawahar Lal Nehru first brought the 
conflict on the UN Security Council agenda on 1 January, 1948. Since then, the UN has been very instrumental in finding lasting solution to the crisis. Its mediation effort finally saw the end of the 1947/48 war (Lorne, 1967: 33-35). Also, during the subsequent wars (1965 and 1971), the UN successfully negotiated cease-fire agreements between the warring parties (Brogan, 1988: 190). Other important secondary parties are the former USSR and China.

\section{INCOMPATIBILITIES}

Historically, the major incompatibility between India and Pakistan concerns the fundamental conflict of the ideological view embodied in the visions of the Congress Party and the Muslim League. As the two leading parties that wielded effective political power within the United British India, and the vanguard in the creation of respective states, their political commitments were intrinsically opposed. While the Congress Party was motivated by the notion of 'secular state', the Muslim League Party followed the ideology of Islamic nationalism (Naidu, 2005: 6). The success of one party meant the undermining of other. These two religions-Islam and Hinduism-lack any sense of tolerance of each other and finally gave rise to two nations within one state (Ganguly, 1986: 3). At another level, the crucial undergirding incompatibility that repeatedly influences the proclivity towards war is anchored on the uncertain status of Kashmir. With the collapse of the British hegemony, the so-called princely states, as already noted, had to join either of the two new Dominions on the basis of geographical location and demographic realities. Because of its strategic location and population, Kashmir posed a special dilemma. Geographically, it is contiguous to both India and Pakistan, while demographically, Kashmir is being dominated by Muslims. For the government of Pakistan, the bone of contention is a question of incorporating Kashmir in its political domain along with all Muslim-majority regions of the former British India Empire for, only then could the Muslim develop their separate cultural ethos (Burke, 1973: 11), and by this also, the incorporation of Kashmir into the state of Pakistan will ensure its "completeness" (Ganguly, 1986: 17).

On the other hand, for the state of India, the incompatibility is that the irredentist claim by
Pakistan over Kashmir is senseless simply because they (Indians) are of the belief that all minorities could thrive well in a predominantly Hindu, but secular state. They argued further that if India were to concede the territories of Kashmir to Pakistan, it would mean that India secularism was merely 'cosmetic', only religion could serve as the basis for a state in South Asia. Based on this, each state-Pakistan and India-keenly aware of the ideological imperative of Kashmir, are most unwilling to concede it to other, as this would undermine its ideological legitimacy. Furthermore, the modality of resolving the conflict is also problematic. This is because, while New Delhi regards the religiously charged conflict over Kashmir's final status as a close bilateral issue and insist that the conflict should be resolved through the Shimla Agreement of July 1972, Islamabad maintains that the Kashmiri problem is an unfinished business of the international mediation. Pakistan considers the 1972 agreement as an additional formula to the already existing UN resolutions. It should be noted that the Shimla Agreement implicitly recognized that Kashmir was an unsettled issue and recommended that the problem would be sorted bilaterally with no third party playing any mediatory role (The Far East and Australasia, 1998; Christian Science Monitor, 1999). This remains a strong incompatibility between the two countries.

\section{DYNAMICS}

In the late 1980 s, precisely 1989 , the Indo-Pak relations reached extremely low ebb as insurrection against Indian rule erupted on the Indian side of the LoC and sporadic cross-firing between the two sets of military posts escalated. At first, the insurgency was homegrown, Kashmiri youth, shouting "Azad" or freedom became guerrillas, trying to send India packing with well laced bombs and high profile kidnappings. The insurrection was further exacerbated by the outlawed Jammu and Kashmir Liberian Front (JKLF) and several other Muslim groups' campaign of civil unrest, bombing of public buildings, terrorism, etc, agitating for their independence or complete unification with Pakistan. Abdul Qayyum Khan, the president of Azad Kashmir, supported these groups. To New Delhi, this was a threat to its nationhood and answered by a quick deployment of troops into Jammu and Kashmir, placed Srinangar, the state 
capital, under indefinite curfew and later the crisis escalated. The Indian authority, however, accused Pakistan of abetting the infiltrators and Kashmir insurgency against the Indian rule by arming and providing training facilities to the militants, an accusation which Pakistan vehemently denied. Islamabad says it is only providing moral and diplomatic supports to the Kashmiri separatists (Europa World Year Book, 1999). Arguably, Pakistan sees this as an opportunity to wage war by proxy and has armed and bent it to its own will.

In February 1990, the situation became tensed after three Pakistani civilians were shot dead (by the Indian Police) when they attempted to cross the cease-fire line into the Indian control Kashmir. In this violence, 80 Kashmiris were killed and hundred also sustained injuries. The assistance given to the government at this time was internal political factor that helped Pakistan as the opposition parties expressed their sympathy for the Muslim in Jammu and Kashmir and urged the government to take more active measures towards the crisis. As the exchange of bellicose statements between New Delhi and Islamabad aggravated the already charged relations, the timely intervention of the US saved the situation as the US special envoy to the two countries helped to diffuse the tension in April 1990. The following months were characterized by fighting and skirmishes between the two troops along the Kashmir border (The Far East and Australasia, 2000).

Hopes for improved relations were raised in January 1991 when New Delhi and Islamabad agreed to exchange the Instrument of Ratification regarding the December, 1988 agreements not to attack each other's nuclear facilities. Also in April of the same year, both countries moved a step closer to peace when the two countries' Minister of Foreign Affairs signed agreement "providing that both side would not intimate troops movements and that each other's aircraft would be allowed to fly over and land in their territories through specified air corridors" (Ibid). It is disheartening to note that in spite of these positive developments, peace continues to elude the vale of tear as no permanent solution was found to this perennial problem, which resulted in frequent skirmishes along the LoC. Faced with the bewildering arrays of problems, especially from the radical Pakistani members of the JKLF, the government appealed for peace and in
February 1992, Pakistani forces were deployed to prevent the planned protest marches by the militants in Azad Kashmir. This greatly averted the danger of large-scale confrontation between India and Pakistan. In this and other subsequent clashes, the JKLF suffered heavy causalities. Throughout 1993, the Indo-Pak relations were characterized by tension and hostilities. In 1994, the poisoned relationship took a new course as the two countries embarked on diplomatic offensive against each other. In February, the United Nations High Commission for Human Rights favoured India by getting the withdrawal of the Pakistani's hostile resolution condemning alleged human rights abuses by the Indian forces in Kashmir. This was a real diplomatic gain for New Delhi. Islamabad on the other hand succeeded in securing the passage of resolution condemning reported violations of human rights by the Indian troops in Kashmir at the summit meeting of the Organization of the Islamic Conference (OIC) held in Casablanca, Morocco. Furthermore, between February 1995 and February 1996, Benazir Bhotto's government organized a nation-wide general strike to express Pakistan solidarity with, and support for the independent movements in Jammu and Kashmir and against the atrocities committed by the Indian security forces.

In the spring of 1999, hostilities escalated when an Indian observation post reported unusual activities in the Indian held sector of Kargil. With this, events took a somewhat different turn. Under the cover of the snow, Indian troops had discovered a substantial group of Islamic guerillas (believed to be Afghan Talibaan) on the Indian side of the LoC. These Muslim mercenaries - about 6,000-laid claim to the "liberation" of 193 sq. km. of "Indian" Kashmir, and if allowed to remain on the land, they would effectively shift forward the frontier of Pakistan's Azad Free State. New Delhi greeted the occasion with fury when it was discovered that the infiltrators were getting supports from the Pakistani military. India intelligence reported that the incursion was unlike the regular rag-tag Muslim infiltrators that occur each spring. This is a large scale, highly organized as well as a wellresourced operation that would have been impossible to mount without Pakistani collusion. This invasion in the words of Gurachan Jagat, the state police chief, "ones are better armed and better trained than we've used to. They are 
professionals, with good radio and heavy explosive". This was interpreted as attempt by Pakistan to redraw the LoC by Indian contravention of the Shimla Agreement. In consequence, India started large-scale military operations to drive out the guerrillas. They have even resorted to air strike against infiltrators, something that was not seen in Kashmir since the last full scale war with Pakistan. The conflict escalated when the two Indian helicopters were shot down and over 400 Indian soldiers were killed (The Far East and Australasia, 2000). There was a de-escalation of tension in July 1999 when Pakistan took a decision to support the withdrawal of all Muslim infiltrators from Indian-controlled Kashmir. In August 1999, Indo-Pak relations deteriorated and hostility aggravated when the Indian army at Gujarat shot down a Pakistani naval patrol aircraft. All the 16 people on board were killed. Since this period, the simmering Kashmir issue has been continuously poisoning the relations between the two countries even in this early part of the new millennium.

\section{SYMPTOMS}

In this conflict, both the attitudes and behaviours of the parties involved are characterize by radical postures with intense extremism and hostility with India and Pakistan pit against each other in a fight to the last of the Kashmiri. To Islamabad, possession of Kashmir is a matter of life and death and has tried (and still trying) to provoke the uprisings further by supporting militarily and funding the militant Kashmiri against what it regarded as infidels. The term 'Infidels' which is being used to describe Hindu Indians emphasizes the hostile attitude or hatred that Pakistan and the Muslim Kashmiri have towards India. This hostile attitudes or hatred so to say can be deciphered in the words of Muhammad Yussuf Mir, a wounded Muslim Kashmir policeman of an India grenade attack who vowed, "whoever did this, I hate them, I curse them, I will kill them". The Indian government regards Pakistan as a garrison state with strong connection with terrorists and fanatic organizations such as JKLF and the Afghan Talibaan; with strong missile links with China and North Korea, which salivates at the prospect of swallowing Kashmir. New Delhi also regards Muslim Pakistan as 'rascal', warmonger and unwilling to compromise for the sake of peace.
Since 1990, India has continued to stamp out the revolt with all fury of an enraged elephant. The 'policy of suppression' or 'bullet for bullet' pursued in Kashmir did virtually nothing to crush the unpopular unrest or bring back people to the national mainstream. Instead, it has besmeared India's good name the world over with international condemnation for human rights violations. International human rights organizations declared that thousands Kashmiri (Muslim and Hindus) lost their lives in the crisis. Activists said that over 3000 Kashmiris were killed in the first two years of the disturbances; most of them by the Indian army and reporters uncovered horrifying details of the tortured inflicted on prisoners (Kashmir Times, 29 June, 1998). The estimated number of people killed between 1997 and 1998 ranged from 200,000 to 3,000,000 (Calvocoressi, 1998). However, from New Delhi vantage point, India deserves to be commended for restraint and caution. This view was succinctly put by Governor Girish Saxena, 'We've kept out response low-keyed and measured. We did not use tanks and armed personnel carriers. We have generally confirmed our response to small arms, and have made an impression on people that we are trying to deal with the situation in a civilized way" (New York Times 12 August, 1999).

\section{POWER RELATIONS}

The power relations among the parties involved in this conflict is characterised by a high degree of asymmetry. Despite the fact that both India and Pakistan are nuclear power with secondstrike capability, there is a disproportion in the strength of their armed forces. Numerically, India's armed forces grew from 280,000 in 1949 to over 1,360,000 in 1990 (Brtadnock, 1990: 2). By 2000, the strength of the India's armed forces totaled 1,175,000 (The Far East and Australasia, 2000). With about 200,000 strong Border Security Force (based mainly in the trouble state of Jammu and Kashmir) warily guarding against a Pakistani attack with sophisticated weapons such as grenade launchers, automatic riffles, high-tech military helicopters, etc. Fighting the guerrillas is now largely left to 125,000 others from Paramilitary units and the State Police. Additionally, New Delhi through the state (Indian Kashmir) has armed over 180,000 villagers-Hindus of Jammu and Kashmir - to defend themselves. They are called the Village Defense Committee (Arnold, 
1997: 54). With a population of over $846,302,688$ (1991) (The Far East and Australasia, 2000), and unprecedented increase in Gross National Product, Gross Domestic product, and Per Capita Income serve as tangible economic resources that support the annual increase in her defense budget of Rs. 346,868,100,000 (1999/2000), while Pakistan total military strength was 587,000 (including 513,000 reserves) with defense budget of Rs. 142,000,000 in 1999/2000 (Arnold, 1997: 54).

However, Kashmir militant groups are militarily weak. They have between 40,000 and 45,000 active trained fighters at their disposal and a lot of sympathizers that are readily available in time of emergency. The most important sources of arms and fund are from Pakistan and other proIslamic groups such as the Afghan Talibaan. These coupled with considerable cash flow from the wealthy Muslim Kashmiri worldwide account for the economic resources of these groups. Despite these weaknesses, the militants enjoy the support of the local populace (Muslim Kashmiri) who want "Azad" freedom. This grassroot support constitutes the psychological resources that always raise the fighting moral of the militants

\section{SETTLEMENT PROPOSALS}

There have been quite a number of attempts to find a pacific settlement to the Kashmir conflict, but they have all failed. In January 1984, a third party - namely the United Nations-negotiated a peaceful settlement of the conflict by the United Nations Conciliation Commission (UNCIP) to secure a cease-fire, which came into operation on the first day of 1949, and a fair plebiscite. The UN resolutions of 1948/1949 remained unimplemented for years for a variety of reasons about which perceptions differ. However, the cease-fire collapsed as a result of the hostilities between the two countries. Efforts to resolve the conflict via bilateral talks proved abortive consequent on the rigid posture adopted by the two countries, which completely ignored the premise that the will of the people of Jammu and Kashmir should prevail in such matters. For example, the Tashkent Accord was signed between India and Pakistan, which intended to bring peace, but later collapsed. In July 1972, the famous Shimla Agreement came into force. This accord, signed by Prime Minister Indira Ghandi and Pakistan President Bhutto, called for maintaining the status quo and settling their differences peacefully. These two agreements brought no fruitful results. This is because the agreements considered the conflict as a territorial dispute between the two states, ignoring the principal party in the dispute, that is, the people of Kashmir. The 1972 Shimla Accord in particular, considered the Jammu and Kashmir problem as a question between India and Pakistan, the people of the area were not taken into account. Nonetheless, the agreement did refer to the "final settlement between Jammu and Kashmir". While committing both countries to "settle their differences by peaceful means, through bilateral negotiations or by other peaceful means mutually agreed upon by them, it envisaged further discussions for the establishment of peace and normalization of relations including......... a final settlement of Jammu and Kashmir". As good as the goals of the Shimla Agreements were, the ensuing hostilities and skirmishes along the LoC completely violated the spirit of the Accord. The Lahore Declaration (February, 1999) between the Indian Prime Minister Atal Behari Vajpayee and his Pakistani counterpart Nawaz Sharif marked a significant milestone in thawing the poisoned Indo-Pak relationship. The declaration called for, amongst other things, talks in Kashmir and steps to avoid nuclear war. The presence of Pakistani officers participating in the attacks along side with mercenaries in the Indian territory made it clear that the good objectives of the Lahore Declaration have been forgotten.

\section{SUMMING UP}

This article has analysed the Indo-Pak war, its genesis and dynamics. It is therefore imperative to suggest some possible solutions to the conflict based on our findings. It is important that the crisis needs to be addressed with serious commitment by India and Pakistan, if not, peace will not return to the people of Jammu and Kashmir. The perennial hostilities between the two countries clearly show that the solution to the crisis cannot come via the barrel of the gun. Militancy in Jammu and Kashmir is the product and not the cause of the problem. Unless the fundamental cause of militancy and the people's disenchantment is tackled, no worthwhile and lasting solution is possible. India and Pakistan should realize that this is more of religious problem with political colouration and cannot be tackled with armed contest. The two 
countries should deal with it as simply as a law and order problem. Hence a political solution that could satisfy the urges and aspirations of the people of Jammu and Kashmir living in all regions and areas and belonging to all faiths and communities, that could be eventually acceptable to the two parties is called for. Furthermore, India and Pakistan should realize that the crisis is not territorial only, the demands of the people of Jammu and Kashmir should be taken into consideration and respected. This calls for a plebiscite/referendum in the disputed region to enable them to decide their future.

\section{NOTES}

1. This study is inspired by Barry Bearak's article titled, "The Vale of Tears: Kashmir, A Jewel caught in a Vise of Hatred", New York Times, 12 August, 1999 and was first presented as a seminar paper to BICS 2000 at the Department of Peace and Conflict Research, Uppsala University, Uppsala, Sweden. I thank Muhammed Athar and Ravina Kaur of Pakistan and India respectively for their invaluable comments on the initial draft of the manuscript. Special thanks to Mary-Jane Fox and Goshka Wojtasik both from the Department of Peace and Conflict Research, Uppsala University, Uppsala, Sweden.

\section{REFERENCES}

Arnold, Guy: The Resources of the Third World. Fitzroy Dearbon Publishers, Chicago (1997)
Barry, Bearak: Vale of Tears: Kashmir, A Jewel Caught in a Vise of Hatred. New York Times 12 August (1999). Bercovitch, Jacob and Jackson, Richard: International Conflict: A Chronical Encyclopedia of Conflicts and their Management, 1945-1995. Congressional Quarterly, Washington (1996).

Brogan, Patrick: World Conflict. Bloomsbury Publishing Plc., London (1988).

Brown, Norman: The US and India, Pakistan, Bangladesh. Harvard University Press, Massachusset (1972)

Brtanock, Robert: India's Foreign Policy. The Royal Institute of International Affairs, London (1990).

Burke, S.M.: Mainspring of Indian and Pakistan Foreign Policies. University of Minnesota Press, Minneapolis (1947).

Burke, S.M.: Pakistan Foreign Policy: Historical Analysis. Oxford University Press, London (1975).

Calvocoressi, Peter: World Politics Since 1945. Longman, London (1998).

Christian Science Monitor 7 July (1999).

Europa World Year Book, Volume II (1999).

Ganguly, Summit: The Origin of War in South Asia: IndoPakistani Conflict Since 1947. Westview, Boulder (1986).

Guptar, Sisisr: Kashmir: A Study of Indo-Pakistani Relations. Asian Publishing House, New Delhi (1973). The Kashmir Times, 29 June, 1998.

Lorne, Kavic: India's Quest for Security, 1947-1965. The University of California Press, Berkeley (1967).

Naidu, M.V.: A Multiculturalism and secessionism in the Federation of India and Canada. Peace Research: The Canadian Journal of Peace Studies, 37(1) (2005).

Sreedhar and Kamiyalil, John: Indo-Pak Relations: A Documentary Study. ABC Publishing House, New Delhi (1986).

The Far East and Australasia. 1999. 30th Edition. Europa Publications Ltd., London (1998).

The Far East and Australasia. 2000. 31st Edition. Europa Publication Ltd., London (1999). 